\title{
Settlement of Divorce Lawsuit Due to Conversion is Reviewed from Religious Court Authority
}

\author{
Ida Nursaadah ${ }^{1}$, Zudan Arief Fakrulloh ${ }^{2}$ \\ Borobudur University ${ }^{12}$ \\ \{idaunbor@gmail.com ${ }^{1}$, cclsis@yahoo.com²
}

\begin{abstract}
Divorce is a break in the marriage bond between the two parties, namely husband and wife because of a broken family relationship disharmony. Many factors lead to divorce. One of the factors that cause divorce is because one of the partners has changed religions, so it is not possible to maintain the household because they want to maintain their respective beliefs. Even though according to the constitution, religious belief is the most basic human right, it needs to be respected by anyone. From this point of view, it is logical to change religions as one of the reasons for divorce. With a divorce, each party can practice their religious teachings well, as well as looking for partners who share the same faith. From the point of view of the interests of education, mental and religious development of children, it will be more beneficial to be under the guidance of a single parent than under two opposing faiths. The provisions regulating marriage in Indonesia are Law Number 1 of 1974 concerning Marriage which has been amended by Law Number 16 of 2019. Meanwhile regarding the authority of the Religious Courts based on Law Number 7 of 1989 concerning the Religious Courts which have been amended by Law Number 3 of 2006 and the second amendment to Law Number 50 of 2009. This study examines and answers problems regarding the authority and legal basis that can be used by the Religious Courts to settle a lawsuit for divorce because one party has changed religions. This research is descriptive normative legal research. The approach used is statutory and conceptual.
\end{abstract}

Keywords: divorce lawsuit; convert; authority; Religious Court

\section{Introduction}

Marriage is a human right guaranteed by the constitution of the 1945 Constitution of the Republic of Indonesia. This right has been guaranteed in the 1945 Constitution as stated in Article 28B paragraph (1), that is that everyone has the right to form a family and continue their offspring through a legal marriage.

Marriage is legal if it is done according to the law of each religion and belief and each marriage is recorded according to the prevailing statutory regulations.[1] Marriage is aimed at creating a happy, eternal, and harmonious family. As stated in Article 3 of the Compilation of Islamic Law which states that "the purpose of marriage is to create a family that is sakinah, 
mawaddah, and warahmah". In Islam, the purpose of marriage is to uphold the religion of Allah SWT, in the sense of obeying Allah's commands and prohibitions.[2]

The provisions regulating marriage in Indonesia are regulated in Law Number 1 of 1974 concerning Marriage which has been amended by Law Number 16 of 2019. The phenomenon that occurs now is that divorce often occurs so that the goal of marriage to create a sakinah, mawaddah, and warahmah family cannot be achieved. This is due to various causal factors which are the reasons for divorce. In certain cases, there is a lawsuit, in which a wife files for divorce from her husband due to disputes and quarrels that are no longer possible to maintain her household based on her husband's conversion to the religion.

Usually what happens is that at first, the marriage takes place because of love alone or sheer material factors, not because of the intention of worship following the orders of Allah SWT and His Messenger. What happens is that at first the husband adheres to a non-Islamic religion which then converts to Islam because of marriage and he also makes a marriage contract in Islam. However, during the household trip for some time, it turned out that the husband had changed religions by reverting to his original religion. If the husband and wife do not have a problem, there will be no dispute that results in divorce. Besides, the right of everyone to embrace a religion and worship according to their religion is a human right guaranteed by Article 28E paragraph (1) of the 1945 Constitution. Thus, everyone has the right to embrace any religion that is believed.

Likewise, Islam guarantees freedom of religion, does not force someone to leave religion or force adheres to a particular religion. It's just that according to Islamic law, if a man who has the status of a husband commits infidelity, that is, changes his religion (convert) from Islam to another religion, while his wife continues to embrace Islam then the marriage becomes fasid (fasakh).[3] The reality that happens is that this conversion has triggered conflict and arguments so that there is no hope of living in harmony again in the household. As the best way is for the wife to file for divorce to the Religious Court, which is an Islamic judicial institution. has the authority to adjudicate cases, one of which is a marriage case. A divorce is filed because divorce is a last resort for the wife if there is a household problem that has no solution, especially if the husband has changed religions, which according to him is considered a broken promise.

Divorce due to conversion is not regulated in Law Number 1 of 1974 concerning Marriage. However, in Law Number 1 of 1974 several things can be used as reasons for divorce, which are regulated in Article 38, and for reasons of divorce because one of the parties has changed religions (murtad) is regulated in Article 116 letter (h) of the Compilation of Islamic Law which states that in the event of a religious conversion or apostasy which results in harmony in the household by one of the parties between husband and wife.

As for the authority of the Religious Courts regulated in Law Number 7 of 1989 concerning the Religious Courts which has been amended by Law Number 3 of 2006 and the second amendment to Law Number 50 of 2009. The Religious Courts have authority based on Article 49 of the Law Number 3 of 2006 concerning Amendments to Law Number 7 of 1989 concerning the Religious Courts, which states that the Religious Courts have the duty and authority to examine, decide, and resolve cases at the first level between people who are Muslim, one of which is in the field of marriage. Divorce is a marital affair.

Based on the background, the settlement of a divorce lawsuit due to conversion in terms of the authority of the Religious Court is important and draws the attention of the author to examine and discuss further. It is important to study and discuss it based on a positive legal point of view in the Marriage Law and the Compilation of Islamic Law, as well as other laws and regulations. 


\section{Research Problem}

Based on the background described above, this research problem can be formulated as follows: How is the settlement of divorce lawsuit due to conversion reviewed from religious court authority?

\section{Research Method}

This research method is carried out with a normative juridical approach, which refers to the legal norms contained in statutory regulations and court decisions as well as norms that live and develop in society.[4] The approach used in this research is a statutory approach and a conceptual approach.

\section{Discussion}

Article 1 of Law Number 1974 concerning Marriage states that marriage is a physical and mental bond between a man and a woman as husband and wife to form a happy and eternal family (household) based on the Supreme Lordship. Meanwhile, the definition of marriage according to Article 2 of the Compilation of Islamic Law is marriage, which is a very strong contract or mitssaqan ghalidzan to obey Allah's orders and carry out it is worship.

Marriage is a contract or agreement to legalize sexual relations between a man and a woman to create happiness filled with a sense of peace and affection in a way that is blessed by Allah SWT. In simple terms, a contract or agreement occurs if two people, if they have the will or ability, are combined in one provision and stated in words, or something that can be understood as such, then a legal event called an engagement occurs. Because the contract is what allows the husband to have sex with a woman. If there was no contract there would be no relationship.[5]

In Islam, marriage is an order of Allah SWT and it is also ordered by the Prophet that marriage is recommended because it is beneficial not only for oneself but also for the household, community, nation, and state. Besides, by doing this marriage, someone will avoid temptation from the devil, both through the eyes and through the genitals or lust, desire, and so on. Wirjono Prodjodikoro stated that marriage is the coexistence of a man and a woman who meet certain conditions, and if observed, basically marriage is an agreement that binds physically and mentally based on faith.[6] According to Subekti, marriage is a legal relationship between a man and a woman for a long time.[7] Marriage is one of the sunnatullah that was deliberately created by Allah SWT which, among other things, aims to continue the offspring and other purposes.[8]

Another definition is that marriage is an engagement agreement between a man and a woman to carry out the life of husband and wife, live in a household, and continue the offspring by religious provisions.[9] Ahmad Sudirman Abbas stated that marriage by humans is a divine instinct to reproduce to regenerate which will inherit the noble task of carrying out God's mandate as the Caliph on earth.[10] A marriage can be said to be valid if it is carried out according to applicable law or religion which is regulated in Article 2 of Law Number 1974, which reads:

a. Marriage is legal if it is carried out according to the law of each religion and belief.

b. Every marriage is recorded according to the prevailing laws and regulations. 
According to Article 4 of the Compilation of Islamic Law that marriage is valid, if it is carried out according to Islamic law under Article 2 paragraph (1) of Law Number 1 of 1974 concerning Marriage. Furthermore, to ensure the orderliness of marriage for the Muslim community, every marriage must be recorded. The registration of the marriage is carried out by the Marriage Registration Officer as regulated in Law No. 22 of 1946 in conjunction with Law No. 32 of 1954.[11]

The main purpose of marriage, namely to worship Allah, is called so because of the existence of marriage as an impetus to follow the orders of Allah and His Messenger. Whereas the purpose of marriage based on Article 3 of the Compilation of Islamic Law is to form a happy and eternal family (household) based on the One Godhead and to create a family that is sakinah, mawaddah, and rahmah. According to Soemiyati, the purposes and benefits of marriage are divided into five things, namely:[12]

a. Obtaining legal offspring who will carry on offspring and develop human tribes. The offspring in their marriage have a primary and important purpose both for themselves and for general interests.

b. To achieve an instinctive demand or desire for human nature. God created humans with gender, namely male and female.

c. Keeps people from evil and damage. One of the factors that cause people to easily fall into crime and corruption is the influence of sexual and sexual desire. This is because humans are weak in controlling their passion for passion.

d. Forming and managing a household which is the very basis of a large society based on love and affection.

e. Cultivate activities in trying to find legitimate sustenance and enlarge a sense of responsibility.

However, the goals of the marriage that the husband and wife want to achieve sometimes do not arrive. The marriage goal is not achieved that is expected, because, in the course of a marriage, the reality that occurs in a household is the opposite between the two parties, namely husband and wife, there has been a dispute because one of the parties, in this case, the husband, has changed religions.

Because these disputes result in the unhappiness of the household so that the inner and outer relationships of husband and wife are not harmonious. Thus, the purpose of marriage as outlined in Article 1 of Law Number 1 of 1974 and Article 3 of the Compilation of Islamic Law if allowed will add harm to the inner and outer life of both parties, therefore divorce is the best way for both of them to be free from suffering prolonged mind.

According to Subekti, divorce is one of the events that can occur in a marriage, the divorce is the abolition of marriage by the decision of a judge or the demand of one of the parties to the marriage.[7] H.A. Fuad Sa'id that what is meant by divorce is the breaking up of the marriage between the husband and the wife because there is no harmony in the household or other reasons, such as the infertility of a wife or husband and after previously seeking peace by involving the families of both parties.[13] Meanwhile, according to Islamic fiqh, divorce is also called talaq. According to Islamic law terms, talaq can mean:[14]

a. Eliminate marital ties or reduce attachments by using certain words.

b. Release the marital ties and end the husband-and-wife relationship.

c. Breaking the marriage bond by saying divorce or something equivalent to it.

Based on Article 38 of Law Number 1 of 1974, a marriage can break up because: a. death, b. divorce and c. on the Court's decision. The same provisions are regulated in Article 113 of the Compilation of Islamic Law. Then according to Article 39 paragraph (1) of the same law states that Divorce can only be carried out before a Court Session after the Court concerned 
has tried and failed to reconcile the two parties. Furthermore, Article 39 paragraph (2) of the same law states that to divorce there must be sufficient reason that husband/wife will no longer be able to live harmoniously as husband/wife in the household.

The statement of Article 39 paragraph (2) above, is emphasized again in Article 19 of Government Regulation Number 9 of 1975 concerning the Implementation of Law Number 1 of 1974 concerning Marriage that divorce can occur for reasons or reasons:

a. One party commits adultery or becomes a drunkard, stuffing, gambler, etc. that is difficult to cure;

b. One party leaves the other party for 2 (two) consecutive years without the permission of the other party and valid reason or due to anything beyond his ability;

c. One of the parties received a sentence of 5 (five) years imprisonment or a heavier sentence after the marriage took place;

d. One party commits cruelty or severe persecution that endangers the other party;

e. One of the parties has a disability or illness as a result of not being able to carry out his duties as a husband/wife;

f. Between husband and wife, there are constant quarrels and quarrels and there is no hope of living peacefully again in the household.

The points mentioned above are in Article 116 of Presidential Instruction No.1 of 1991 concerning Dissemination of Compilation of Islamic Law, Book I on Marriage Law, the reasons for divorce are added with 2 things, namely:
a. Husband violates taklik divorce;
b. religious conversion or apostasy which causes dissonance in the household.

It should be remarked that both Islamic law and Law No. 1 of 1974 on Marriage adhere to the principle of complicating divorce. This means that there will be no arbitrary acts in demanding the holding of divorce along with all the consequences of the divorce. Thus, the purpose of marriage as referred to in Article 3 Compilation of Islamic Law, is to form a happy (permanent) family (household) based on the Almighty God and to realize a loving family, mawaddah, and rahmah will be achieved, if the husband and wife carry out what is allowed or forbidden in the marriage rules.

In the case of suing for divorce due to changing religions often happens is one party, namely the previous husband adhering to a non-Islamic religion which then when he will carry out the marriage, the non-Islamic party converts to Islam and enters a marriage contract according to Islamic law. However, on the way to the household, the husband who was previously non-Muslim returned to embracing his original religion. Moreover, the party who changes religions invites their partner to embrace the religion they originally followed, and the party invited to persist in defending their beliefs, which eventually results in a quarrel in the household.

As it is known that to realize a loving family life, mawaddah, and warahmah under the teachings of Islam, each husband and wife must sekufu or equal degree, that is, religious equality. According to four sects namely Syafii, Maliki, Hambali, and Hanafi agree that kufu must be fulfilled in marriage is in terms of religion.[15]

The quarrels caused by differences of opinion/understanding because each party maintains their beliefs lead to disputes resulting in the unhappiness of the household so that the goal is to form a happy and eternal family (household) based on Almighty God and to create a sakinah family, mawaddah and rahmah are not achieved. Disputes between husband and wife in Islamic law are called Syiqaq.[16] Besides, it results in the inner and outer relationship of the husband and wife becoming disharmonious and leading to divorce against one of the parties. That is because, in this context, the husband has converted or has apostatized by returning to 
his original religion. The initiative for divorce can occur at the husband's initiative, at the wife's initiative, with the consent of both parties, or through a court decision.[17]

Divorce legally valid positive can only occur if it is done in front of the Religious Court either because the husband who dropped the divorce (talaq) or because the wife sued for divorce or the so-called divorce contested, namely the wife sued her husband for divorce through the courts, then the court in favor referred to so that the plaintiff's (wife) relationship with the defendant ends.[4] In Islam, a marriage can break up due to divorce and is considered valid even if only by the husband's verbal words. Even though it has been spoken verbally, legally it must still be done in front of the Religious Court. It intends to protect all rights and obligations that arise as a result of the divorce law. Therefore, it must be submitted to the local Religious Court as a Religious Court institution. This is as regulated in Article 40 of Law Number 1 of 1974, that a divorce suit is filed at the Court and the procedure for filing a lawsuit is regulated in separate laws and regulations.

According to Article 1 number 1 of Law Number 50 of 2009 concerning the Second Amendment to Law Number 7 of 1989 concerning the Religious Court, the Religious Court is a court for people who are Muslim. Meanwhile, what is meant by the Court is the religious court and the high religious court within the religious court.[18] Furthermore, according to Article 2 of Law No. 3 of 2006 on Amendments to Law No. 7 of 1989 concerning Religious Court, the Religious Court is one of the perpetrators of judicial power for Muslim justice seekers on certain matters as referred to in the Law this.

The authority to judge or the competence of the court's jurisdiction is to determine which court is authorized to examine and decide cases so that the filing of the case can be accepted and rejected because the court is not authorized to try it. The authority to judge is a formal requirement for the validity of a lawsuit, so filing a case to a court that is not competent to judge causes the lawsuit to be deemed wrong and unacceptable because it is not by the absolute authority or the relative authority of the court.

The authority to judge or the absolute jurisdictional competence of the Religious Courts is regulated in Article 49 of Law Number 3 of 2006 concerning Amendments to Law Number 7 of 1989 concerning the Religious Courts, which states: "Religious courts have the duty and authority to examine, decide, and resolve cases at the first level among Muslims in the field of: a. marriage; b. inheritance; c. will; $d$. grant; e. waqf; f. zakat; g. infaq; h. sadaqah; and $i$. sharia economy ". This article is an amendment and expansion of the authority of the Religious Courts previously regulated in Article 2 of Law Number 7 of 1989 concerning the Religious Courts.

Meanwhile, relative authority or competence is the power and authority granted between courts within the same court or authority relating to the jurisdiction between Religious Courts within the Religious Courts.[17] Another definition of relative authority is the power of the judiciary which is of one kind and one level, in contrast to the powers of the court of the same type and level. The power or authority granted to the court in a judicial environment of the same type and level as related to the jurisdiction of the court and the residence area or domicile of the litigant.[19]

Based on this absolute authority, the Religious Court has the authority to adjudicate divorce cases which are matters of marriage as regulated in Article 49 of Law No. 3 of 2006 on Amendments to Law No. 7 of 1989 on Religious Courts.

Generally, at the beginning of the examination of the matter in the Religious Court, the Judiciary will first try to reconcile the couple who will be divorced. When there is a reconciliation, then the divorce application is considered void and the husband and wife remain the legal husband and wife. However, because this is a matter of divorce because the 
husband converted and it is a very personal matter that will be difficult to achieve peace as attempted by the Judiciary.

In the case of a divorce lawsuit because one of the parties in this case the husband converted, the Judiciary will decide the matter with a decision fasakh, which is the divorce of the marriage at the will of the Judge as a third party. But in his consideration, it is not always decided fasakh, but based on other considerations. The fasakh decision was taken by the Judge even in the pettitum primair of the divorce petitioner requesting that the Judicial Council grant the divorce application. It often happens that the Judiciary decides outside the plaintiff's application, but this is an ex officio right, that is, a judge's right because his office decides or gives something that is not in the lawsuit, so he can decide more than what is demanded, even if it is not demanded by the parties to the matter.

It should be noted that Article $178 \mathrm{HIR}$ and Article 189 paragraph (3) of $R b g$ states that the Judge is prohibited from making decisions on matters that are not demanded or granting more than required. This prohibition is called ultra petitum partium. However, there are exceptions, as in the case of divorce, the Judge is allowed to decide outside the claim/application. It is intended for the benefit and upholding justice for both parties to the matter.

In his consideration, the Judge was also based on the plaintiff's statement and supported by evidence and corroborated by the testimony of the divorce plaintiff witnesses. Based on this, the Panel of Judges can conclude that regarding the disharmony of husband and wife's household caused by the statement of the plaintiff and supported by evidence and corroborated by the statements of the plaintiff's witnesses, the Panel of Judges concludes that regarding the domestic disharmony that occurs. a dispute because one of the parties has changed religions (apostasy). Especially if there is information explaining that the two places have been separated so that the marriage which is carried out by both parties through the Islamic religion by itself has been damaged (broken). This is following the intent of Article 19 letter $\mathrm{f}$ of Government Regulation Number 9 of 1975 in conjunction with Article 116 letter (h) Compilation of Islamic Law which is one of the reasons for divorce and by the Panel of Judges and the witnesses, as well as the family, have sought peace between the plaintiff and the defendant, but without success.

Thus, the Panel of Judges decides cases based on Article 19 letter f Government Regulation Number 9 of 1975 which reads: "Between husband and wife there are constant disputes and quarrels and there is no hope of living in harmony again in the household" and Article 116 letter h of Compilation. Islamic law, namely "conversion of religion or apostasy which causes disharmony in the household". In this case, the Judge's decision is not due to the husband's apostasy, but rather emphasizes disputes/quarrels and there is no hope of living in harmony again in the household.

\section{Conclusion and Suggestion}

\subsection{Conclusion}

The existence of an inviolable divorce in the community which is submitted by a wife to the Religious Court is due to disputes and quarrels so that there is no hope of living in harmony again in the household based on the husband's conversion to the religion. Even though under Islamic law, their marriage is automatically canceled because they changed religions. The Religious Court, in this case, will only decide on a legal divorce by emphasizing the consideration that between husband and wife there are constant disputes and 
quarrels and there is no hope of living in harmony again in the household and there is no harmony in the household. Divorce in this context is the best way so that each party can practice their religious teachings.

\subsection{Suggestion}

Muslim women should be more careful in choosing a spouse, preferably one with the same faith in the sense of one religion. This is intended so that there are no household problems even though the husband has converted to Islam and entered into an Islamic marriage contract. Marriage is not just loving or material even though it is not of the same faith, but it must be deeply and carefully considered the risks that will occur when a husband converted by returning to his original religion. If the husband and wife already have children, then for the spiritual and religious development of the children, it will be more beneficial to be under the guidance of a single parent, namely a mother, rather than taking shelter under two opposite or different beliefs.

\section{References}

[1] Law of the Republic of Indonesia Number 1 of 1974 concerning Marriage

[2] Hadikusuma, Hilman .: Indonesian Marriage Law. Printing I, Mandar Maju, Bandung (1990)

[3] Sabiq, Sayyid .: Fiqh Sunnah, Translation: Nor Hasanuddin, Volume 3, Pena Pundi Aksara, Jakarta (2006)

[4] Ali, Zainnudin .: Indonesian Islamic Civil Law. New Indonesian Society Foundation, Palu (2002)

[5] Kuzari, Ahmad .: Marriage as a Bond. Rajawali Press, Jakarta (1995)

[6] Prodjodikoro, Wirdjono .: Marriage Law in Indonesia. Wells, Bandung (1981)

[7] Subject: Principles of Civil Law. Cet. XXIX, Intermasa, Jakarta (2001)

[8] Hassan, Muhammad Ali .: Guidelines for Household Life in Islam. Siraja, Jakarta (2003)

[9] Mukhtar, Kamal .: Principles of Law About Marriage. Bulan Bintang, Jakart (1974)

[10] Abbas, Ahmad Sudirman .: Introduction to Marriage, Comparative Analysis between Schools. Prima Heza Lestari, Jakarta (2006)

[11] Presidential Instruction of the Republic of Indonesia Number 1 of 1991 concerning Dissemination of Compilation of Islamic Law

[12] Soemiyati .: Islamic Marriage Law in the Marriage Law (Law Number 1 of 1974 concerning Marriage), Liberty, Yogkarta (1986).

[13] Sa'id, H.A. Fuad .: 1994, Divorce according to Islamic Law, Pustaka Al Husna, Jakarta.

[14] Hamid, Zuhri .: Principles of Islamic Marriage Law and Marriage Law in Indonesia. Bina Cipta, Yogyakarta (1988).

[15] Syaukani, Al Imam Muhammad Asy .: Nailul Authar. Volume VI, Asy Syifa, Semarang (2001).

[16] Syarifudin, Amir .: Islamic Marriage Law in Indonesia. Prenada Media, Jakarta (2006).

[17] Wahyudi, Abdullah Tri :. Religious Courts in Indonesia. Student Library, Jakarta (2004). 
[18] Law of the Republic of Indonesia Number 50 of 2009 concerning Second Amendment to Law Number 7 of 1989 concerning Religious Courts.

[19] Renita .: Authority of the Religious Courts, Legal Aid Foundation for the Protection of Parahyangan Catholic University.

[2] Retrieved from http://lbhpengayoman.unpar.ac.id/kewayaan-pengadilangama/\#: :text=Semporary\%20itu\%2C\%20kompetensi\%20relatif\%20 is, or\% 20 powers $\% 20$ to adjudicate\% 20antar\% 20 of the court. \& Text $=$ In conclusion\% 2C\% 20 competence\% 20 absolute\% 20 Court\% 20 Religion\% 20 Islam\% 20 at\% 20First 20\% rate, 20 November 2020

[21] Soeroso .: Civil Procedure Law. Sinar Grafika, Jakarta (2010).

[22] Law of the Republic of Indonesia Number 7 of 1989 concerning Religious Courts

[23] Law of the Republic of Indonesia Number 3 of 2006 concerning Amendments to Law Number 7 of 1989 concerning the Religious Courts

[24] Law of the Republic of Indonesia Number 16 of 2019 concerning Amendments to Law Number 1 of 1974 concerning Marriage

[25] Government Regulation of the Republic of Indonesia Number 9 of 1975 concerning Implementation of Law Number 1 of 1974 concerning Marriage 